\title{
ANALISIS ASPEK GRAMATIKAL DAN LEKSIKAL PADA CERPEN KETEK IJO KARYA M. FAJAR KUSUMA
}

\section{AN ANALYSIS OF GRAMATICAL AND LEXICAL ASPECTS OF KETEK IJO SHORT STORY WRITTEN BY M.FAJAR KUSUMA}

\author{
Julisah izar,Rengki Afria dan Dimas Sanjaya \\ Sastra Indonesia, Faultas IImu Budaya Universitas Jambi \\ julisahizar@unja.ac.id, rengki afria@unja.ac.id dan dimassanjaya5@yahoo.co.id
}

Naskah diterima: 7 Mei 2019; direvisi: 31 Mei 2019; disetujui: 20 Juni 2019

\begin{abstract}
ABSTRAK
Tujuan dari penelitian ini adalah untuk mengetahui: (1) Bagaimana bentuk kohesi gramatikal yang terdapat pada cerpen Ketek ljo karya M.Fajar Kusuma dan (2) Bagaimana bentuk kohesi leksikal pada cerpen Ketek ljo karya M.Fajar Kusuma Jenis penelitian ini adalah kualitatif deskriptif. Data dianalisis dengan menggunakan metode padan dan agih. Metode padan yang digunakan adalah metode padan referensial dengan teknik lanjutan unsur pilah penentu (PUP), yaitu dengan memilah kalimat-kalimat yang memiliki penanda kohesi gramatikal dan leksikal. Teknik dasar yang digunakan dalam metode agih adalah bagi unsur langsung (BUL). Keabsahan data diperoleh dari ketekunan pengamatan dan triangulasi. Instrumen penelitian adalah humant instrument.

Peneliti menjadi alat pengumpul data utama sekaligus menganalisis langsung data yang telah dikumpul tersebut Hasil penelitian menunjukkan hal-hal berikut. Pertama, bentuk penanda kohesi gramatikal yang muncul adalah referensi, substitusi, konjungsi, dan elipsis. Kedua, bentuk kohesi leksikal yang muncul adalah repetisi, sinonimi, antonimi, hiponimi, kolokasi dan metonimia.
\end{abstract}

Kata kunci : Kohesi gramatikal, kohesi leksikal , cerpen.

\section{ABSTRACT}

The aims of this research are to know: (1) What is the form of grammatical cohesion that is exposed to the Ketek ljo short story by M. Fajar Kusuma. (2) What is the form of lexical cohesion in the Ketek ljo short story by M. Fajar Kusuma. This research is qualitative descriptive. Data were analyzed using the equivalent and final method. The matching method used is a referential equivalent method with advanced determinant elements techniques, namely by sorting sentences that have markers of grammatical and lexical cohesion. The basic technique used in the agih method is for the direct element. The validity of the data is obtained from perseverance of observation and triangulation.

The research instrument is a humant instrument. The researcher became the main data collection tool while directly analyzing the data that had been collected. The results showed the following. First, the markers of grammatical cohesion that emerge were references, substitutions, conjunctions, and ellipses. Second, the forms of lexical cohesion that emerge were repetition, synonymy, antonym, hyponym, collocation and metonymy. Keywords: Grammatical cohesion, lexical cohesion, short story.

\section{PENDAHULUAN}

\section{Latar Belakang}

Pada dasarnya sarana komunikasi verbal

dibedakan menjadi dua jenis, antara lain sarana komunikasi yang berupa bahasa

lisan dan sarana komunikasi yang berupa bahasa tulis (Sumarlam, 2003:

1). Dengan demikian, wacana atau 
tuturan pun dibagi menjadi dua macam, yaitu wacana lisan dan wacana tulis. Wacana adalah satuan bahasa terlengkap dan tertinggi atau terbesar di atas kalimat atau klausa dengan kohesi dan koherensi yang berkesinambungan yang mempunyai awal dan akhir yang nyata disampaikan secara lisan atau tertulis (Tarigan, 2009: 26). Sebuah wacana dikatakan baik apabila hubungan antar kalimat-kalimatnya kohesif dan koheren. Kohesi merujuk pada bentuk, artinya kalimat-kalimat yang membangun paragraf itu haruslah berhubungan secara padu. Kohesi dibagi menjadi dua jenis yaitu kohesi gramatikal dan kohesi leksikal. Penanda aspek kohesi gramatikal terdiri dari, pengacuan (referensi), penyulihan (substitusi), penghilangan (elipsis), dan kata penghubung (konjungsi). Penanda aspek kohesi leksikal ini, repetisi (pengulangan), sinonim (persamaan), antonim (lawan kata), hiponim (hubungan bagian atau isi), kolokasi (sanding kata), dan ekuivalensi.

Pengkajian sebuah karya sastra prosa merupakan sebuah tantangan karena komunikasi yang ada di dalamnya bersifat abstrak. Abstrak dalam hal ini artinya apa yang ingin disampaikan penulis belum tentu sama dengan apa yang dipahami oleh pembaca setelah membacanya. Dalam memahami karya sastra prosa tidaklah cukup hanya dengan memahami makna kata-katanya saja tetapi juga harus dibekali dengan pengetahuanpengetahuan pendukung seperti sosial, budaya, dan pemahaman terhadap masyarakat pemakai bahasa itu sendiri apalagi cerpen yang dikaji ini memiliki campuran bahasa Melayu Jambi. Tujuan dari penelitian ini adalah mendeskripsikan Penanda kohesi gramatikal antar kalimat yang terdapat pada cerpen Ketek Ijo karya M.Fajar Kusuma. Mendeskripsikan penanda kohesi leksikal antar kalimat yang terdapat pada cerpen Ketek Ijo karya M.Fajar Kusuma. Adapun alasan dalam penelitian ini penulis ingin lebih lanjut mengkaji wujud penanda kohesi gramatikal dan leksikal antar kalimat yang terdapat dalam cerpen Ketek Ijo karya M.Fajar Kusuma.

\section{TEORI}

\section{Pengertian Wacana dan Analisis Wacana}

Menurut (Kridalaksana, 1983 : 179). Wacana adalah satuan bahasa terlengkap; dalam hierarki gramatikal, merupakan satuan gramatikal tertinggi atau terbesar Lebih lanjut dikatakan 
bahwa wacana ini direalisasikan dalam bentuk karangan yang utuh (novel, buku, seri ensiklopedia, dan sebagainya), paragraf, kalimat atau kata yang mambawa amanat yang lengkap. Wacana mrupakan suatu satuan tertinggi dari hierarki gramatikal bahasa yang di dalamnya sudah terkandung keutuhan yang lengkap dan membawa amanat tertentu.

Senada dengan Kridalaksana, Tarigan mengemukakan bahwa wacana adalah satuan bahasa yang terlengkap dan tertinggi atau terbesar di atas kalimat atau klausa dengan koherensi dan kohesi yang tinggi yang berkesinambungan yang mempunyai awal dan akhir nyata disampaikan secara lisan atau tertulis (Kridalaksana, 1983 : 27). Pendapat tersebut tidak hanya mendasarkan pada wacana sebagai satuan tertinggi tetapi juga di dalamnya menuntut adanya suatu koerensi dan kohesi yang tinggi dan mempunyai awal dan akhir yang nyata.

(Chaer, 2013: 75) juga berpendapat bahwa wacana adalah satuan bahasa yang lengkap, sehingga dalam hierarki gramatikal merupakan satuan tertinggi atau terbesar Pendapat ini sama dengan pendapat dari Kridalaksana, bahwa wacana merupakan satuan bahasa yang tertinggi secara gramatikal.

Dalam kaitannya dengan analisis wacana terdapat pula beberapa pendapat dari beberapa ahli bahasa. Stubbs (dalam Oetomo, 1993 : 4) menyatakan bahwa analisis wacana merujuk pada upaya mangkaji pengaturan bahasa di atas kalimat atau klausa, dan karenanya mengkaji satuan-satuan kebahasaan yang lebih luas, seperti pertukaran percakapan atau teks tertulis. Pendapat tersebut mempunyai konsekuensi adanya suatu pengkajian terhadap unsur-unsur di luar aspek linguistik, yang turut memberi andil dalam terbentuknya suatu wacana.

$$
\text { Senada dengan Stubbs, }
$$

Kartomihardjo menyatakan bahwa analisis wacana merupakan cabang ilmu bahasa yang dikembangkan untuk menganalisis suatu unit bahasa yang lebih besar daripada kalimat dan lazim disebut wacana. Cukup sederhana pengertian tersebut, jadi analisis wacana lebih pada suatu pengkajian suatu unit bahasa yang lebih besar daripada kalimat.

Berangkat dari beberapa pendapat di atas dapat disimpulkan bahwa analisis wacana adalah suatu upaya pengkajian bahasa pada tataran di 
atas kalimat atau klausa yang juga melibatkan aspek-aspek di luar aspek linguistik yang turut memberi makna terhadap suatu bahasa yang digunakan tersebut.

\section{Aspek Gramatikal}

Satu bahasa terdiri atas bentuk (form) dan makna (meaning), maka hubungan antar bagian wacana dapat dibedakan menjadi dua jenis, yaitu hubungan bentuk yang disebut kohesi (cohesion) dan hubungan makna atau hubungan semantik yang disebut koherensi (coherence) (Sumarlam, 2005 : 23). Lebih lanjut lagi, menurut Halliday dan Hasan (1976: 6) membagi kohesi menjadi dua jenis yaitu kohesi gramatikal (grammatical cohesion) dan kohesi leksikal (lexical cohesion). Struktur lahir wacana atau segi bentuk disebut aspek gramatikal wacana, struktur batin wacana atau segi makna disebut aspek leksikal wacana.

Aspek gramatikal wacana meliputi : (1) pengacuan (reference), (2) penyulihan (substitution), (3) pelesapan (ellipsis), (4) perangkaian (conjunction) (Sumarlam, 2005 : 23). Berikut akan dijelaskan lebih lanjut mengenai empat aspek gramatikal tersebut. a. Pengacuan (referensi)
Pengacuan atau referensi adalah salah atau jenis kohesi gramatikal yang berupa satuan lingual tertentu yang mengacu pada satuan lingual lain (atau suatu acuan) yang mendahului atau mengikutinya. Terdapat dua jenis pengacuan yaitu pengacuan endofora dan pengacuan eksofora. Pengacuan endofora apabila acuannya berada dalam teks wacana itu, dan dikatakan pengacuan eksofora apabila acuannya di luar teks wacana.

Pengacuan endofora dibagi menjadi dua jenis yaitu pengacuan anaforis dan pengacuan kataforis. Pengacuan anaforis adalah salah satu kohesi gramatikal yang berupa satuan lingual tertentu yang mengacu pada satuan lingual lain yang mendahuluinya, atau mengacu anteseden di sebelah kiri, atau mengacu pada unsur yang telah disebut terdahulu. Pengacuan kataforis merupakan salah satu kohesi gramatikal yang berupa satuan lingual tertentu yang mengacu pada satuan lingual lain yang mengikutinya, atau mengacu anteseden di sebelah kanan, atau mengacu pada unsur yang akan disebut kemudian. Satuan lingual tertentu yang mengacu pada satuan lingual lain dapat berupa persona (kata ganti orang), demonstratif (kata ganti penunjuk), dan 
komparatif (satuan lingual yang berfungsi membandingkan antara unsur yang satu dengan yang unsur yang lain.

b. Penyulihan (substitusi)

Penyulihan atau substitusi ialah salah satu jenis kohesi gramatikal yan berupa penggantian satuan lingual tertentu (yang telah disebut) dengan satuan lingual lain dalam wacana untuk memperoleh unsur pembeda. Dilihat dari segi satuan lingualnya, substitusi dapat dibedakan menjadi substitusi nominal (kata benda), verbal, frasal, dan klausal.

\section{c. Pelesapan (elipsis)}

Pelesapan atau elipsis adalah salah satu jenis kohesi gramatikal yang berupa penghilangan atau pelesapan satuan lingual tertentu yang telah disebutkan sebelumnya. Unsur atau satuan lingual yang dilesapkan dapat berupa kata, frasa, klausa, atau kalimat.

\section{d. Perangkaian (konjungsi)}

Konjungsi adalah salah satu jenis kohesi gramatikal yang dilakukan dengan cara menghubungkan unsur yang satu dengan yang lain dalam wacana. Unsur yang dirangkai dapat berupa satuan lingual kata, frasa, klausa, kalimat, dan dapat juga berupa unsur yang lebih besar dari itu, misalnya alinea dengan pemarkah lanjutan, dan topik pembicaraan dengan pemarkah alih topik atau pemarkah disjungtif.

\section{Aspek Leksikal}

Kohesi leksikal adalah hubungan antar unsur dalam wacana secara semantis. Hubungan kohesif yang diciptakan atas dasar aspek leksikal, dengan pilihan kata yang serasi, menyatakan hubungan makna atau relasi semantik antara satuan lingual yang satu dengan satuan lingual yang lain dalam wacana. Kohesi leksikal dalam wacana dapat dibedakan menjadi enam macam, yaitu (a) repetisi (pengulangan), (b) sinonimi (padan kata), (c) kolokasi (sanding kata), (d) hiponimi (hubungan atas-bawah), (e) antonimi (lawan kata), dan (f) ekuivalensi (kesepadanan).

$$
\text { a. Repetisi (pengulangan) }
$$

Repetisi atau pengulangan adalah pengulangan satuan lingual (bunyi, suku kata, kata, atau bagian kalimat) yang dianggap penting untuk memberi tekanan dalam sebuah konteks yang sesuai. Berdasarkan tempat satuan lingual yang diulang dalam baris, klausa atau kalimat, repetisi dibedakan lagi menjadi delapan macam, yaitu repetisi epizeuksis (pengulangan satuan lingual yang penting beberapa kali secara berturut-turut), tautotes (pengulangan 
satuan lingual, sebuah kata, beberapa kali dalam sebuah konstruksi), anafora (pengulangan satuan lingual berupa kata atau frasa pertama pada tiap baris atau kalimat berikutnya), epistrofora (pengulangan satuan lingual kata/frasa pada akhir baris dalam puisi atau akhir kalimat dalam prosa), sinekdoke (pengulangan satuan lingual pada awal dan akhir beberapa baris/kalimat berturut-turut), mesodiplosis (pengulangan satuan lingual di tengahtengah baris atau kalimat secara berturut-turut), epanalepsis (pengulangan satuan lingual yang kata/frasa terakhir dari baris/kalimat itu merupakan pengulangan kata/frasa pertama), dan anadiplosis (pengulangan kata/frasa terakhir dari baris/kalimat itu menjadi kata/frasa pertama pada baris/kalimat berikutnya).

\section{b. Sinonimi}

Sinonimi dapat diartikan sebagai nama lain untuk sebuah benda atau hal yang sama; atau ungkapan yang maknanya kurang lebih sama dengan ungkapan lain. Sinonimi merupakan salah satu aspek leksikal untuk mendukung kepaduan wacana. Berdasarkan wujud satuan lingualnya, sinonimi dapat dibedakan menjadi lima macam, yaitu (1) sinonimi antar morfem (bebas) dengan morfem (terikat), (2) kata dengan kata, (3) kata dengan frasa atau sebaliknya, (4) frasa dengan frasa,

$$
\text { klausa/kalimat dengan }
$$

klausa/kalimat.

c. Antonimi (lawan kata)

Antonimi dapat diartikan sebagai nama lain untuk benada atau hal yang lain; atau satuan lingual yang maknanya berlawanan beroposisi dengan satuan lingual yang lain. Berdasarkan sifat oposisi makan dapat dibedakan menjadi lima macam, yaitu (1) oposisi mutlak (contoh: hidup-mati), (2) oposisi kutub (contoh: kaya-miskin), (3) oposisi hubungan (contoh: bapak-ibu), (4) oposisi hirarkial (contoh: kilogram-ton), (5) oposisi majemuk (contoh: berdirijongkok-duduk-berbaring).

\section{d. Kolokasi (sanding kata)}

Kolokasi adalah asosiasi tertentu dalam menggunakan pilihan kata yang cenderung digunakan secara berdampingan. Kata-kata yang berkolokasi adalah kata-kata yang cenderung dipakai dalam suatu domain atau jaringan tertentu, misalnya dalam jaringan pendidikan akan digunakan kata-kata yang berkaitan dengan masalah pendidikan dan orang-orang yang terlibat di dalamnya. Misalnya kata sawah, petani, lahan, bibit padi, 
sistem pengolahan, panen, dan hasil panen akan sering dijumpai dalam jaringan pertanian.

e. Hiponimi (hubungan atasbawah)

Hiponimi dapat diartikan sebagai satuan bahasa (kata, frasa, kalimat) yang maknanya dianggap merupakan bagian dari makna satuan lingual yang mencakupi beberapa unsur atau satuan lingual yang berhiponim itu disebut hipernim atau superordinat. Contoh : binatang melata $=$ reptil $\Rightarrow$ katak, ular, cicak, kadal, bunglon.

\section{f. Metonimia}

Metonimia adalah sebuah gaya bahasa yang memakai suatu kata untuk mengungkapkan kata lainnya karena memiliki hubungan yang erat. Biasanya terjadi pada barang menggunakan merk untuk menyebutkan benda tersebut. Misalnya: Honda (motor), odol (pasta gigi) dan infokus (proyektor).

\section{METODE PENELITIAN}

\section{Jenis dan Desain Penelitian}

Jenis penelitian ini adalah penelitian deskriptif kualititatif. Artinya penelitian ini bertujuan untuk mendeskripsikan bentuk-bentuk satuan lingual dalam kohesi gramatikal dan leksikal pada cerpen Ketek Ijo karya M.Fajar Kusuma. Instrumen penelitian adalah humant instrument. Peneliti menjadi alat pengumpul data utama sekaligus menganalisis langsung data yang telah dikumpul tersebut (Moleong, 2006: 168). Metode analisis data yang digunakan pada penelitian ini adalah metode padan dan agih. Metode padan yang dipakai dalam penelitian ini menggunakan alat penentu kenyataan atau fakta yang ditunjuk oleh bahasa atau disebut dengan padan referensial. Teknik lanjutan yang dipakai adalah teknik pilah unsur penentu (PUP). Pelaksanaan teknik lanjutan ini adalah dengan memilah kalimat-kalimat dalam sebuah cerpen yang memiliki penanda kohesi antar kalimat tersebut. Metode agih adalah metode penelitian bahasa yang alat penentuanya justru bagian dari bahasa yang bersangkutan (Sudaryanto, 1993: 15). Dalam penelitian ini alat penentunya adalah satuan lingual yang merupakan bentuk penanda kohesi gramatikal dan leksikal. Teknik dasar yang digunakan dalam metode ini adalah teknik bagi unsur langsung (BUL). Pelaksanaan teknik bagi unsur langsung (BUL) ini adalah dengan membagi wacana menjadi beberapa kalimat yang kemudian atara satu kalimat dengan kalimat yang lain dicari dan dianalisis bentuk penanda 
kohesinya. Teknik lanjutan dari teknik dasar BUL adalah dengan menggunakan teknik pelesapan atau delesi. Hasil analisis disajikan dalam bentuk informai, yaitu dengan menyajikan data melalui penjelasan atau deskriptif. Keabsahan data diperoleh dengan ketekunan pengamatan.

\section{HASIL}

\section{Kohesi Gramatikal}

Kohesi gramatikal adalah perpaduan wacana dari segi bentuk atau struktur lahir wacana (Sumarlam, 2003: 40). Penanda aspek gramatikal ini terdiri dari, pengacuan (referensi), penyulihan (substitusi), penghilangan (elipsis), dan kata penghubung (konjungsi).

\section{Referensi}

Berdasarkan Jenis Halliday dan Hasan (1979) membedakan referensi menjadi dua macam, yaitu eksoforis dan endoforis.

a) Eksoporis

Referensi eksoforis adalah pengacuan satuan lingual yang terdapat di luar teks wacana.

1) "Sayo ko anaknyo anak Pakte Derani, anak paling terakhir"

2) "Tergantung pemimpin la Bang, Sayo Cuma kerjo bae, bukan merintah Bang".
3) "Yo Bang, berangkat dulu. Assalamualikum”.

Dari data di atas refernsi eksoporis digunakan untuk merujuk diri sendiri. Dalam cerpen pengacuan diri sendiri hanya ditemukan pada dialog antar tokoh. Karena konteks situasi adalah bahasa Melayu Jambi, maka bahasanya menggunakan bahasa Melayu Jambi.

Dari data (1) frasa anak paling terakhir mengacu kepada sayo. Pada data (2) terjadi penghilangan pada kalimat bukan merintah Bang. Hal itu dapat dimaknai sebagai pengacuan sayo. Pada data (3) tidak ada kata saya akan tetapi karena dialog dapat dimaknai ada "saya" yang berbicara.

b) Endoporis

Referensi endofora adalah pengacuan satuan satuan lingual yang terdapat di dalam teks wacana.

1) Satu persatu penumpang naik ke Ketek Bang Leman. Mereka cuman punya satu tujuan yaitu menyebrangi sungai menuju Kota Jambi.

2) anak Bang Leman masih berdiri di Pangkalan bersama Rio, tentu dia menunggu sesuatu dari ayahnya.

3) "Yah, Amri nak berangkat" Dengan nada lembut diutarakan maksudnya waktu telah berlalu 
dan sang anak tak ingin terlambat masuk sekolah.

Pada data (1) satuan lingual mereka mengacu pada kata penumpang. Begitu pula pada data (2) dia mengacu pada frasa Anak Bang Leman. Pada data (3) terjadi dalam konteks dialog, Amri sebagai nama lalu pada kalimat selanjutnya digunakan frasa sang anak. Konteks ini terjadi dari sudut pandang penulis.

Berdasarkan Tipe:
a) Personal

Orang Pertama

1. Bang, masih ingat Sayo?

2. Sayo ko anaknyo anak Pakte Derani, anak paling terakhir.

3. Iyo Bang, makonyo Sayo pakek ketek be berangkatnyo

4. Kalo Sayo bagian perencanaan pembangunan kota

5. Tergantung pemimpin la Bang, Sayo Cuma kerjo bae, bukan merintah Bang.

6. Heh, Sayo jugo dak tau Bang

Dari semua data di atas terjadi

pada konteks situasi dialog. Pada cerpen ini memakai sudut pandang orang ketiga. Jadi penggunaan kata Saya hanya ditemukan pada teks dialog bukan dari narasi cerita.

Orang Kedua

1) Siapo kau ko?

2) Ya Allah, lupo nian Abang, berapo lamo kau disano la?

3) Kau apo kabar? Macemano kota Jakarta kiniko?
4) Mantap, kuliah jurusan apo kau Rio?

5) Hah, kau bangun la dusun kau ni biak bagus.

6) Iyo Mri, belajar elok-elok iko duit jajan kau.

7) Iko ko duo pupu kau, pokoke masih keluargo kito Mri.

Dari semua data di atas terjadi pada konteks situasi dialog. Pada cerpen ini memakai sudut pandang orang ketiga. Jadi penggunaan kata kau hanya ditemukan pada teks dialog bukan dari narasi cerita. Pada contoh di atas ditemukan pula bahasa Melayu Jambi

Orang ketiga

1) Mereka cuman punya satu tujuan yaitu menyebrangi sungai menuju kota jambi.

2) Disanalah pusat keramaian, berbeda dengan di pinggiran kota ini, daerah sebrang mereka mengenalnya.

3) "Itu diok, duduk paling depan". Menunjuk anaknya dengan rasa bangga.

4) "Meninggal waktu ngelahirin diok”. Bang Leman memelankan suaranya.

5) Satu persatu penumpang turun dengan menyodorkan uang lima ribu, anak Bang Leman masih berdiri di Pangkalan bersama Rio, tentu dia menunggu sesuatu dari ayahnya.

6) Namun ia lagi-lagi harus melakukan itu sendiri dan juga Amri harus menggantungkan botol minumnya di leher dan meneteng kantong plastic hitam untuk bekal saat jam istirahat.

Pada data (1) dan

merupakan sudut pandang orang ketiga bentuk jamak. Pada data (3), data (4), data (5) dan data (6) 
merupakan sudut pandang orang ketiga bentuk tunggal. Dari 4 data bentuk tunggal tersebut ditemukan dalam konteks bahasa Melayu Jambi dalam situasi dialog dalam teks yaitu : diok, sedangkan dia dan ia ditemukan dalam narasi cerpen.

b) Demonstratif

Pengacuan demonstratif

direalisasikan melalui pronomina demonstratif (kata ganti penunjuk). Pronomina demonstratif merupakan kata-kata yang menunjuk pada suatu benda atau deiktis yang menunjuk hal umum, tempat, ataupun ihwal

Berikut ini beberapa yang telah didapatkan:

1) Topi berwarna hijau yang telah pudar, berlambangkan kapal pesiar yang lusuh, menandakan bahwa telah berpuluh-puluh tahun lelaki tua itu menekuni pekerjaan ini.

2) Disanalah pusat keramaian, berbeda dengan di pinggiran kota ini, daerah sebrang mereka mengenalnya.

3) Pemuda itu lantas mengucapkan terima kasih dan langsung duduk di kursi kosong paling belakang dekat dengan Bang Leman.

4) Jadi, tak perlu pusing-pusing memikirkan lauk apa hari ini.

5) Pemuda itu tampak gelisah, mungkin karena sungai batanghari telah berubah.

6) Pemuda itu memutar arah tubuhnya dan menghadap ke arah Bang Leman.
7) Pemuda itu berharap seolaholah berharap Bang Leman mengenalnya.

8) Oh, yang kuliah di Jakarta tu yo?

9) Aih, macem tu lah Bang, macet terus disano.

10) Apo kerjo e tu?

11) "Itu diok, duduk paling depan". Menunjuk anaknya dengan rasa bangga.

12) Mantap tu Bang. Istri abang?

13) Tak hanya itu, Pangkalan Angso Duo juga digunakan untuk kapal-kapal ukuran lumayan besar berhenti.

14) Sebagai uang tambahan, itu bisa dikerjakan.

15) Iko nambah dari abang

16) Makasih yah, makasih bang. Maaf bang, Abang ko sapo?

17)Iko ko duo pupu kau, pokoke masih keluargo kito Mri.

18) Namun ia lagi-lagi harus melakukan itu sendiri dan juga Amri harus menggantungkan botol minumnya di leher dan meneteng kantong plastik hitam untuk bekal saat jam istirahat.

19)Ini bukan kehendaknya, ini pemberian dari Tuhan yang harus disyukurinya.

Pengacuan demonstratif

ditemukan 19 unsur yang terdiri dari ini dengan variasi iko dan ko dan itu dengan variasi $t u$. Referensi demonstratif ini digunakan untuk pengacuan tempat dan waktu.

c) Komparatif

Kohesi gramatikal berupa pengacuan komparatif mengacu pada sesuatu yang sedang sedang dibicarakan, unsurnya dapat berupa 
generik, seperti: identitas (sama, sama dengan, seperti, identik , dst.), kemiripan (sama, seperti, tambahan, demikian pula, itu juga, dst.) dan perbedaan (yang lain, berbeda dari, sedangkan, dst.), juga yang bersifat spesifik (lebih banyak, lebih sedikit, kurang, lebih jauh, dst). Dari cerpen Ketek Ijo ditemukan 5 referensi komparatif diantaranya:

1) Kulitnya tampak kecoklatan hampir sama dengan warna air sungai Batanghari.

2) Disanalah pusat keramaian, berbeda dengan di pinggiran koa ini.

3) Hanya sungai Batanghari sebagai pembatas dari kedua sisi yang berbeda.

4) Mungkin karena sungai Batanghari yang telah berubah.

5) "Samolah, Jambi ko la nak macet jugo"

\section{Substitusi}

Penggantian adalah penyulihan suatu unsur wacana dengan unsur yang lain yang acuannya tetap sama, dalam hubungan antarbentuk kata, atau bentuk lain yang lebih besar daripada kata, seperti frasa atau klausa (Halliday dan Hassan, 1979: 88)

Bentuk dari substitusi tersebut terbagi tiga yaitu: nomina, verba dan klausa. Berikut data yang telah didapatkan:
a) Nomina

1) Satu persatu penumpang naik ke ketek Bang Leman. Mereka cuman punya satu tujuan yaitu menyebrangi sungai menuju Kota Jambi.

2) Anak Bang Leman masih berdiri Pangkalan bersama Rio, tentu dia menunggu sesuatu dari ayahnya.

Dari data diatas ditemukan adanya substitusi nomina. Pada data (1) merupakan pergantian unsur satuan lingual penumpang di substitusikan dengan unsur lingual mereka. Kata mereka merujuk pada kata penumpang. Begitu pula pada data (2) merupakan pergantian unsur satuan lingual Rio di substitusikan dengan unsur lingual mereka. Unsur lingual Rio adalah nama orang digantikan menjadi dia yaitu sudut pandang orang ketiga.

b) Verba

1) Bang Leman pun mencoba beberapa kali tarikan sebelum mesin ketek menyala dan terdengarlah suara berisik.

2) Begitulah sungai Batanghari yang berevolusi dari waktu ke waktu, juga pemuda yang duduk dekat dengan Bang Leman.

3) Pemuda itu memutar arah tubuhnya dan menghadap ke arah Bang Leman.

4) "Sayo cuma kerjo bae, bukan merintah Bang"

5) Anak Bang Leman masih berdiri di Pangkalan bersama Rio, tentu dia menunggu sesuatu dari ayahnya.

Dari data diatas ditemukan adanya substitusi verba. Pada data (1) merupakan pergantian unsur satuan lingual menyala di substitusikan dengan 
unsur lingual berisik. Konteks situasi data (1), menyala diartikan suara mesin ketek sehingga kalimat selanjutnya menggunakan kata berisik. Pada data (2) merupakan pergantian unsur satuan lingual berevolusi di substitusikan dengan unsur lingual juga. Unsur lingual berevolusi adalah bentuk verba yang kemudian di substitusikan juga yang merupakan konjungsi.

Pada data (3) merupakan pergantian unsur satuan lingual memutar di substitusikan dengan unsur lingual menghadap. Konteks situasi dari kata verba tersebut sama-sama merujuk ke posisi tubuh dari subjek kalimat yaitu Pemuda itu. Pada data (4) merupakan pergantian unsur satuan lingual kerjo (kerja) di substitusikan dengan unsur lingual merintah (memerintah). Pada data (5) merupakan pergantian unsur satuan lingual berdiri di substitusikan dengan unsur lingual menunggu. Konteks situasi pada data (5) berdiri diartikan sedang menunggu, maka kalimat selanjutnya menggunakan kata menunggu.

c) Klausa

1) Pemuda itu tampak gelisah, mungkin karena sungai Batanghari yang telah berubah.

2) "Mantap, kuliah jurusan apo kau Rio?" mencoba bertanya layaknya seorang yang pernah merasakan memegang kapur tulis.

Pada data (1) merupakan pergantian unsur satuan lingual berwujud klausa Pemuda itu tampak gelisah di substitusikan dengan unsur lingual mungkin. Kata mungkin merujuk langsung ke klausa Pemuda itu tampak gelisah. Pada data merupakan pergantian unsur satuan lingual kuliah di substitusikan dengan unsur lingual berwujud klausa seorang yang pernah merasakan memegang kapur tulis.

\section{Elipsis}

Pelesapan atau elipsis merupakan salah satu jenis kohesi gramatikal yang berupa penghilangan atau pelesapan satuan lingual tertentu yang telah disebutkan sebelumnya. Pelesapan dapat berbentuk kata, frasa, atau klausa. Pada cerpen Ketek Ijo terdapat kalimat yang mengalami pelesapan, dan beberapa telah beri analisis mengenai penambahannya. Data ini tertera pada data berikut:

Topi berwarna hijau yang telah pudar, berlambangkan kapal pesiar yang lusuh, menandakan bahwa telah berpuluh-puluh tahun lelaki tua itu menekuni pekerjaan ini.

Hubungan antarposisi dalam wacana di atas dinyatakan melalui 
pengunaan aspek gramatikal pelepasan (ellipsis). Satuan lingual yang telah disebutkan pada kalimat sebelumnya tidak perlu diulang kembali. Pada data elipsis di atas bagian yang dilepaskan dapat diisi frasa Topi berwarna hijau, jadi penggalan kalimat selanjutnya tidak perlu menggunakan frasa tersebut.

1) "Sayo ko anaknyo anak Pakte Derani, anak paling terakhir"

2) "Tergantung pemimpin la Bang, Sayo Cuma kerjo bae, bukan merintah Bang”.

Pada konteks dialog antar tokoh ditemukan pula pelepasan. Data (1) kata Sayo mengalami pelepasan pada penggalan kalimat setelah koma. Data (2) kata Sayo kembali mengalami pelepasan. Kalimat bukan merintah Bang dapat dimaknai merujuk kepada sayo.

\section{Konjungsi}

Konjungsi disebut juga kata hubung atau kata sambung. Kata penghubung termasuk kata tugas yang berfungsi menghubungkan antar klausa, antar kalimat dan antar paragraf.

a) Konjungsi Sebab akibat

1) Kulitnya tampak kecoklatan hampir sama dengan warna air sungai Batanghari, karena setiap harinya terpapar sinar matahari dari pagi sampai sore.
2) Mencoba mengalihkan pembicaraan, karena mendengar berita baru di kampungnya.

3) Bang Leman menunda menarik tali untuk memutar mesin dan cepat-cepat mengambil papan kecil, sebelum jarak ketek dan pangkalan menjauh, sehingga pemuda itu bisa naik ke ketek.

Pada data (1) dan (2) konjungsi karena digunakan untuk penghubung antara sebab dan akibat, yang mana kalimat awal sebagai sebab -karenakalimat akhir akibat. Begitu pula pada data (3) konjungsi sehingga digunakan untuk antara sebab dan akibat.

b) Konjungsi Pertentangan

1) Delapan kursi beralaskan papan, namun masih ada satu kursi kosong di belakang.

2) Seharusnya ada sosok perempuan yang mengantarnya dan menungguinya hingga pulang sekolah, namun ia lagi-lagi harus melakukan itu sendiri

Pada data (1) dan (2) ditemukan konjungsi namun yang digunakan untuk menandai adanya perlawanan dari kalimat awal dan kalimat akhir.

c) Konjungsi waktu

1) Setelah selesai membuang air sisa di Keteknya.

2) Setelah turun semua, Bang Leman mendekati dua orang tersebut. 
3) Karena setiap harinya terpapar sinar matahari dari pagi sampai sore hari.

4) Akibat hujan lebat semalam..

5) Saat Bang Leman hendak menghidupkan mesin ketek.

6) Sekarang, mesin-mesin penyebab penyedot pasir.

7) Bang Leman menunda menarik tali untuk memutar mesin dan cepat-cepat mengambil papan kecil, sebelum jarak ketek dan pangkalan menjauh, sehingga pemuda itu bisa naik ke ketek.

8) Aneka macam kegiatan banyak terjadi selain disebutkan sebelumnya, jika dingat-ingat kembali

9) Bang Leman pun mencoba beberapa kali tarikan sebelum mesin ketek menyala.

10) Para Ibu segera menutup payung karena sebentar lagi tujuannya sudah di depan mata.

Pada data (1) dan (2) konjungsi setelah digunakan untuk waktu yang terjadi pada konteks situasi pada narasi cerpen. Pada data (3) konjungsi sampai digunakan untuk menerangkan waktu dari waktu sekian hingga waktu sekian. Pada data (4) konjungsi semalam digunakan untuk menerangkan waktu kemarin. Pada data (5) dan (6) konjungsi saat dan sekarang digunakan untuk menerangkan waktu yang sedang berlangsung.
Pada data (7), data (8) dan data (9) konjungsi sebelum digunakan untuk menerangkan waktu pra kejadian. Dan pada data (10) konjungsi sebentar digunakan untuk menerangkan waktu yang sedikit.

d) Konjungsi Tujuan

1) Jadi, tak perlu pusingpusing memikirkan lauk apa hari ini.

Pada data di atas konjungsi jadi digunakan untuk menerangkan tujuan dari kalimat tersebut. Biasanya terdapat di akhir paragraf.

e) Konjungsi Penambahan

1) Pegawai-pegawai yang bekerja di kantor Pemerintahan dan orangorang yang punya keperluan di Kota Jambi

2) Pemuda itu memutar arah tubuhnya dan menghadap ke arah Bang Leman.

3) Bapak-bapak yang sedang mempersiapkan jaring di atas ketek untuk mencari ikan dan orang-orang asing yang sengaja berdiri di pinggiran sungai.

4) Kerikil dan penambang emas illegal di daerah pelosok bertaburan.

5) Lalu, para pencari ikan tak bisa lagi menebar jaring dan berharap ada ikan yang tersangkut.

6) Begitulah siklus penggunaan ketek selain mengangkut manusia dan barangbarang.

7) Begitulah sungai Batanghari yang berevolusi dari waktu 
ke waktu, juga pemuda yang duduk dekat dengan Bang Leman.

Pada data (1) sampai (6) konjungsi dan digunakan untuk penambahan selain itu juga berfungsi untuk menghubungkan secara koordinatif antara klausa yang berada di sebelah kiri dengan klausa yang mengandung di sebelah kanannya.

f) Konjungsi Urutan

1) Lalu, para pencari ikan tak bisa lagi menebar jaring dan berharap ada ikan yang tersangkut.

2) Kapal-kapal tersebut singgah di tengah sungai, lalu ketek-ketek yang telah disewa.

Pada data di atas, konjungsi lalu menandai adanya urutan peristiwa. Biasanya konjungsi urutan untuk menerangkan urutan peristiwa yang sedang berlangsung dari sudut pandang orang ketiga.

g) Konjungsi Perlawanan

1) Anak umur delapan tahun, sudah tangguh harus tangguh melawan kesendirian. Seharusnya ada sosok perempuan yang mengantarnya dan menungguinya hingga pulang sekolah, namun ia lagi-lagi harus melakukan itu sendiri.

Pada wacana di atas, kata seharusnya merupakan penanda konjungsi perlawanan yang menunjukkan adanya ketidakserasian antara proposisi kalimat awal dengan kalimat akhir.

h) Konjungsi Syarat

1) Aneka macam kegiatan banyak terjadi selain disebutkan sebelumnya, jika dingat-ingat kembali kehidupan masyarakat dahulu bergantung pada sungai Batanghari

Pada wacana di atas, kata jika menjelaskan bahwa suatu hal tersebut terjadi jika syarat tersebut terpenuhi. Konteks situasi pada wacana di atas kata jika digunakan untuk menerangkan Aneka macam kegiatan dengan mengingat kembali sebagai pertalian syarat.

i) Konjungsi Penegas

1) Apalagi ditambah tercemarnya air sungai Batanghari.

2) Begitulah sungai Batanghari yang berevolusi dari waktu ke waktu, juga pmuda yang duduk dekat dengan Bang Leman.

3) Akhirnya, ketek Bang Leman menepi dengan santai di Pangkalan ketek Angso Duo.

Konjungsi penegas digunakan untuk menegaskan bagian kalimat yang telah disebutkan sebelumnya. Hal itu dapat terlihat pada contoh di atas.

\section{B. Aspek Leksikal}

\section{Repetisi}

Hanya ikan-ikan yang punya nyali besar untuk mampu 
bertahan dengan kondisi yang memprihatinkan, ikan-ikan predator pada umumnya yang hidup dibagian sungai yang paling dalam. Lalu para pencari ikan tak bisa lagi menebar jaring dan berharap ada ikan yang tersangkut, pada kenyataannya, sampahsampahlah yang tersangkut.

Pada wacana di atas merupakan contoh repetisi penuh. Unsur lingual kata yang diulang penuh ialah ikan-ikan dan ikan.

\section{Sinonimi}

Ketek Bang Leman melaju dengan pelan, menyusuri pinggiran sungai Batanghari.

Pada wacana di atas kata melaju bersinonimi dengan kata menyusuri yang memiliki makna semantic sama, sehingga kata tersebut dapat saling dipertukarkan posisinya dan tidak akan mengubah makna dari wacana tersebut.

\section{Hiponimi}

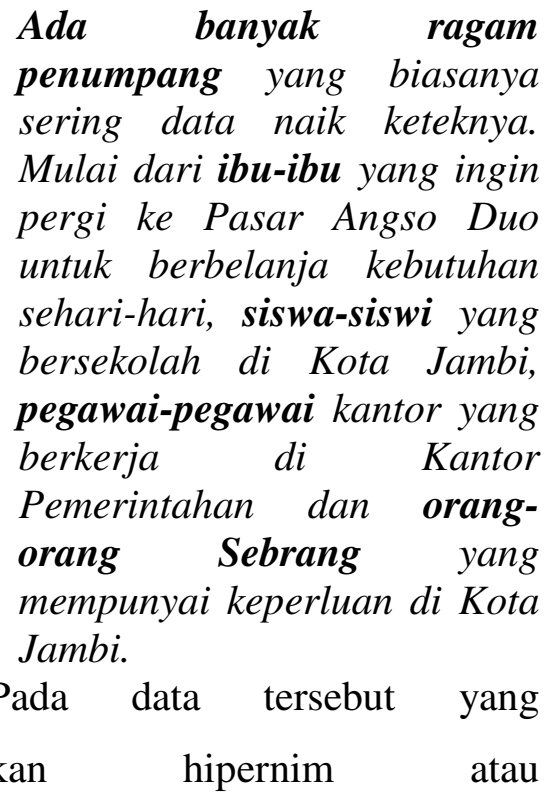

superordinatnya adalah Penumpang Ketek, sedangkan hiponimnya adalah ibu-ibu, siswa-siswi, pegawai Kantor, dan orang berkepentingan.

\section{Antonimi}

1) Air sungai Batanghari masih terus mengalir deras dari hulu ke hilir.

2) Bila di Kota pusat keramaian, disini pusat kesepian.

Pada data (1) lawan kata antara unsur hulu dan hilir merupakan oposisi mutlak karena memiliki pertentangan makna secara mutlak. Kedua kata tersebut memiliki makna yang berbeda. Kata hulu menerangkan di awal sedangkan hilir menerangkan di akhir atau muara. Pada data (2) juga merupakan oposisi mutlak. Kedua kata tersebut memiliki arti yang berlawanan.

\section{Metonimia}

Ketek yang telah disewa digunakan untuk mengantarkan barang-barang para pedagang dari kapal menuju pangkalan ketek Angso Duo dan diangkut oleh para kuli menuju kios para pedagang.

Pada data di atas metonimia kuli digunakan untuk menyebut seseorang yang bekerja untuk orang lain yang bertugas mengangkut-angkut barang. Metonimia kuli adalah metonimia hubungan kausal penanda tersebut dapat saling menggantikan. 


\section{Kolokasi}

Setelah membuang air sisa di keteknya, Bang Leman pun mengambil sebuah papan kecil dari keteknya yang merupakan tempat duduk sebagai jembatan antara keteknya dan pangkalan. Satu persatu penumpang naik ke Ketek Bang Leman.

Pada wacana di atas ditemukan

kolokasi yang berhubungan dengan buruh Ketek (ojek perahu). Kolokasi yang ditemukan ialah: air, papan kecil (jembatan), pangkalan dan penumpang.

\section{KESIMPULAN}

Penggunaan aspek gramatikal yang terdapat dalam wacana "cerpen" terjalin dengan adanya penanda aspek gramatikal yang terdiri dari: (1)Referensi dalam wacana cerpen Ketek Ijo dibagi menjadi dua yaitu: berdasarkan jenis yakni eksoporis dan endoporis. Eksporis mengacu pada diri sendiri (saya). Endoporis mengacu orang lain (mereka dan dia). Berdasarkan tipe terbagi 3 yaitu persona, demonstratif dan komparatif. Persona terdiri dari sudut pandang orang pertama (saya), kedua (kau) dan ketiga (mereka, dia). Demosntratif mengacu pada waktu dan tempat (ini dan itu), dan komparatif mengacu perbandingan (sama, berbeda) (2)Substitusi ditandai dengan adanya bentuk yang berkedudukan sebagai pengganti dan bentuk yang berkedudukan sebagai terganti. Dimana unsur pengganti dapat dikembalikan pada unsur tergantinya. (3)Elipsis ditandai dengan adanya unsur yang dilesapkan yang ditandai dengan simbol $\Theta$ (zero). Ditemukan satu elipsis. (4)Konjungsi ditandai dengan oleh hadirnya kata penghubung yang menghubungkan antar klausa, antar kalimat dan antar klausa-kalimat. Konjungsi yang didapatkan: sebab akibat (karena, sehingga), pertentangan (namun), waktu (setelah, sampai, semalam, saat, sekarang, sebelum, sebentar), tujuan (jadi), penambahan (dan, juga), urutan (lalu), perlawanan (seharusnya), syarat (jika) dan penegas (apalagi, begitulah, akhirnya). Penggunaan aspek leksikal yang terdapat dalam wacana cerpen Ketek Ijo terjalin melalui penanda aspek leksikal yang terdiri dari: (1)Repetisi yaitu pengulangan, hanya ditemukan satu dalam wacana yaitu repetisi penuh. (2)Sinonimi didapatkan dua sinonimi kata dengan kata.(3)Antonimi ditandai dengan kata yang menunjukan oposisi makna, dalam wacana didapatkan dua antonimi kata dengan kata. (4)Hiponimi hubungan atas-bawah didapatkan satu data hiponimi. (5)Metonimia, ditandai 
dengan penggunaan kata untuk menjelaskan kata lainnya (merek).

Dalam wacana didapatkan satu metonimia. (6)Kolokasi ditandai dengan menggunakan pilihan kata yang cenderung digunakan secara berdampingan. Dalam wacana ditemukan satu bentuk kolokasi.

\section{DAFTAR PUSTAKA}

Chaer, Abdul. 2013. Pengantar Semantik Bahasa Indonesia. Jakarta: Rineka Cipta.

Halliday dan Ruqaya Hasan. 1976. Cohesion in English. London: Longman Inc.

Kridalaksana, Harimurti. 1983. Kamus Linguistik. Jakarta: Gramedia.

Moloeng, Lexy. 2006. Metode Penelitian kualitatif. Bandung: Remaja Rosdakarya.

Oetomo, Dede. 1993. "Pelahiran dan Perkembangan Analisis Wacana", dalam Bambang Sudaryanto. 1992. Metode Linguistik Ke Arah Memahami Metode Linguistik. Yogyakarta: Duta Wacana.

Sudaryanto. 1992. Metode Linguistik Ke Arah Memahami Metode Linguistik. Yogyakarta: Duta Wacana.

Sumarlam. 2003. Analisis Wacana: Teori dan Praktik. Surakarta: Pustaka Cipta.

Sumarlam (ed). 2005. Analisis Wacana. Surakarta : UNS Press

Tarigan, Henry Guntur. 1987. Pengajaran Wacana. Bandung: Angkasa. 